Economics Development Analysis Journal

\title{
Analisis Faktor - Faktor yang Mempengaruhi Remitansi di Kabupaten Cilacap
}

\section{Anggriawan Wisnu Putra ${ }^{\bowtie}$}

Honda Motor

\section{Info Artikel}

Sejarah Artikel:

DiterimaJuni 2016

Disetujui Juli 2016

Dipublikasikan Agustus 2016

\section{Keywords:}

Income, Family Needs, Personal Consumption, Remittance

\begin{abstract}
Abstrak
Tujuan penelitian ini adalah untuk mengetahui pengaruh pendapatan, kebutuhan keluarga di daerah asal dan pengeluaran konsumsi TKI terhadap remitansi baik secara simultan maupun parsial. Populasi dalam penelitian ini meliputi seluruh tenaga kerja yang pernah dan akan berangkat menjadi TKI di kabupaten Cilacap sebanyak 50 orang. Adapun sampel yang digunakan dalam penelitian ini adalah Purpossive Sampling dimana semua anggota populasi digunakan sebagai sampel. Variabel yang digunakan dalam penelitian ini adalah pendapatan (X1), kebutuhan keluarga (X2), konsumsi pribadi (X3) dan remitansi (Y). Metode pengumpulan data yang digunakan dalam penelitian ini melalui wawancara terstruktur dengan menggunakan kuesioner. Analisis data yang digunakan adalah analisis regresi linier berganda dengan SPSS rilis 17. Hasil penelitian menunjukkan pendapatan dan kebutuhan keluarga berpengaruh positif dan signifikan terhadap remitansi, sedangkan konsumsi pribadi berpengaruh negatif signifikan terhadap remitansi. Simpulan dari penelitian ini yaitu secara parsial pendapatan dan kebutuhan keluarga berpengaruh positif dan signifikan terhadap remitansi. Ketika pendapatan dan kebutuhan keluarga meningkat maka remitansi akan meningkat begitu pula sebaliknya. Sedangkan konsumsi pribadi memiliki pengaruh negatif signifikan terhadap remitansi, yang berarti ketika konsumsi pribadi mengalami kenaikan maka remitansi mengalami penurunan. Sedangkan secara simultan model regresi dapat digunakan untuk memprediksi remitansi. Variabel pendapatan berperan sebagai variabel paling dominan mempengaruhi remitansi.
\end{abstract}

\section{Abstract}

The purpose of this study was to determine the effect of income, family needs in the area of origin and consumption expenditure of remittances migrant workers against either simultaneously or partially. The population in this study are the entire workforce ever and will go into migrant workers in Cilacap regency with the number of sample are 50 people. The sample used in this study is the purpossive sampling where all members of the population used as sample. Variables used in this research are Income (X1), the family needs (X2), private consumption (X3) and remittances ( $Y$ ). Data collection methods used in this study through interviews using a structured questionnaire. The data analysis used is linear regression analysis with SPSS release 17. The results showed that Income and Family Needs had a positive and significant effect against to remittances, while private consumption had significantly negative influence Against to remittances. This study concludes that partially income and family needs had positive and significant impact on remittances. When income and family needs increases, remittances will increase and vice versa. While private consumption has a significant negative effect on remittances, which means when the personal consumption increases then remittances decreased. While simultaneously obtained the regression model can be used to predict remittances. Variable income serves as the most dominant variable affecting to remittances.

(C) 2016 Universitas Negeri Semarang

\footnotetext{
Alamat korespondensi:
}

JL Laksda Yos Sudarso, Sunter I J1 Raya Pegangsaan 2 km 2.2

ISSN 2252-6765

Kelapa Gading Jakarta 14350

E-mail: anggriawanwisnu@gmail.com 


\section{PENDAHULUAN}

Menurut Pasal 1 bagian (1) UndangUndang nomor 39 Tahun 2004 tentang penempatan dan perlindungan tenaga kerja Indonesia di luar negeri, TKI merupakan setiap warga negara Indonesia yang memenuhi syarat untuk bekerja di luar negeri dalam hubungan kerja untuk jangka waktu tertentu dengan menerima upah, pada bagian (2) TKI di artikan bahwa setiap warga negara Indonesia yang memenuhi syarat sebagai pencari kerja yang akan bekerja di luar negeri dan terdaftar di instansi pemerintah kabupaten/kota yang bertanggung jawab di bidang ketenaga kerjaan (Apriliana, 2013). Perpindahan faktor tenaga kerja ke luar negeri salah satunya disebabkan oleh perbedaan pendapatan antara di daerah asal dan di luar negeri. Sebagian TKI (Tenaga Kerja Indonesia) memilih bekerja di luar negeri untuk meningkatkan kesejahteraan keluarganya melalui pekerjaan yang lebih baik dan pendapatan yang lebih tinggi di negara tujuan bekerja. Menurut (Adams JR. \& Cuecuecha, 2013) Penerimaan remitansi sangat mengurangi kemungkinan kemiskinan dalam rumah tangga.

Sepanjang tahun 2012 Indonesia mengirim faktor tenaga kerja ke luar negeri (TKI) sebanyak 586.802 orang yang dikirim ke berbagai negara dari seluruh provinsi di Indonesia. Provinsi Jawa Tengah merupakan daerah yang berada di urutan kedua terbanyak dalam mengirim tenaga kerjanya ke luar negeri dengan jumlah TKI sebanyak 344.581 orang (BNP2TKI, 2014). Dan kabupaten pengirim TKI terbesar di Jawa Tengah adalah kabupaten Cilacap dengan rata-rata pengiriman TKI sebanyak 19.841 orang per tahun.

Pendapatan TKI yang bekerja di luar negeri memberikan pengaruh positif terhadap daerah asal melalui remitansi yang dikirimkan kepada keluarganya. Salah satu sumber devisa yang penting untuk pengembangan yang negara adalah Remitansi (Guha, 2013). Menurut Ardana, dkk (2011), Pendapatan diartikan sebagai hasil yang diperoleh setelah bekerja, sedangkan pendapatan pribadi diartikan sebagai semua jenis pendapatan, termasuk pendapatan yang diperoleh tanpa memberikan suatu kegiatan apapun, dan diterima oleh penduduk suatu negara (Sukirno,2004:46). Tingkat konsumsi dan tabungan ditentukan oleh tingkat pendapatan rumah tangga (Sukirno, 2004:119), bagi keluarga di daerah asal, remitansi merupakan pendapatan yang diterima dari keluarga yang bekerja di luar negeri, sehingga konsumsi keluarga di daerah asal dipengaruhi oleh pendapatan yang diterima. Hal ini yang mempengaruhi remitansi yang dikirim oleh TKI. Pengeluaran konsumsi TKI selama bekerja di luar negeri ikut serta memberikan dampak pada besar remitansi yang dikirim kepada keluarganya (Faiqoh, 2009).

Salah satu variabel penting remitansi yang mempengaruhi adalah pendapatan migran. Semakin banyak pendapatan imigran, semakin banyak uang yang dikirim ke negara asal (R. Aísa et al., 2011). Tingkat penerimaan remitansi Kabupaten Cilacap sebagai penyalur TKI terbesar di Jawa Tengah terus mengalami kenaikan secara signifikan setiap tahunnya hingga mencapai Rp 280.015.151.000 pada tahun 2014. Hal ini menunjukkan adanya konsistensi teori yang dikemukakan Sukirno (2004:119) mengenai tingkat konsumsi dan tabungan ditentukan oleh tingkat pendapatan rumah tangga yang tercemin dengan kenaikan KHL Kabupaten Cilacap. Namun tingkat penerimaan remitansi Kabupaten Cilacap tidak sebesar Kabupaten Kendal. Kedua Kabupaten tersebut sama-sama berasal dari Provinsi Jawa Tengah yang berada di sepuluh besar tingkat Kabupaten pengirim TKI terbanyak di Indonesia. Kabupaten Cilacap menerima total remitansi dari tahun 2011-2014 sebesar 841.562.812.000 sedangkan Kabupaten Kendal menerima total remitansi dari tahun 2011-2014 sebesar 1.100.426.595.719.

\section{Hipotesis}

H1: Ada pengaruh pendapatan TKI terhadap remitansi pada Kabupaten Cilacap

H2: Ada pengaruh tingkat kebutuhan keluarga TKI terhadap remitansi pada Kabupaten Cilacap 
H3: Ada pengaruh tingkat konsumsi TKI Cilacap terhadap remitansi pada Kabupaten

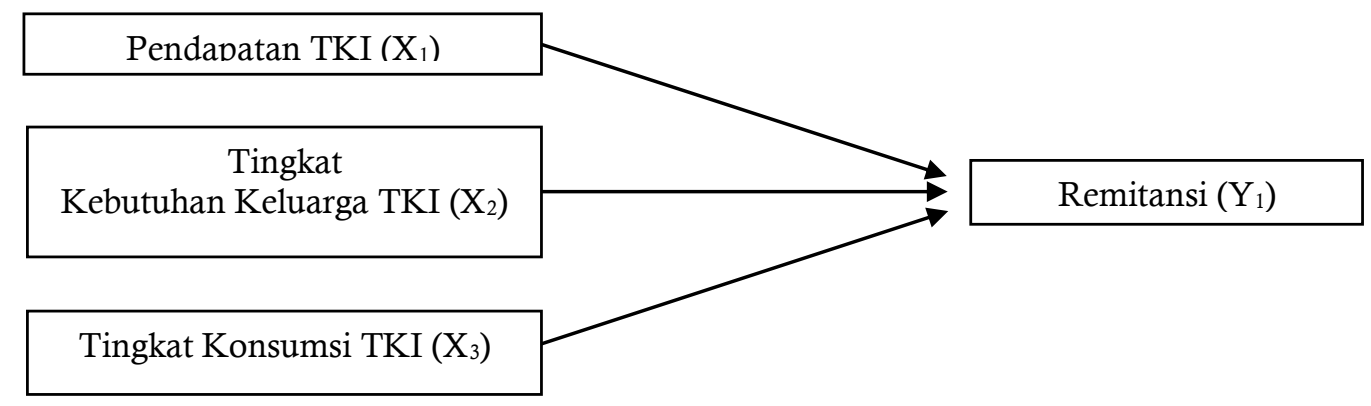

Gambar 1. Model Penelitian

\section{METODE PENELITIAN}

Populasi dalam penelitian ini adalah seluruh tenaga kerja yang pernah dan akan berangkat menjadi TKI di kabupaten Cilacap. Teknik pengambilan sampel yang digunakan adalah Purpossive Sampling dimana pengambilan sampel secara sengaja sesuai dengan persyaratan sampel yang diperlukan dengan menentukan kriteria apa yang digunakan. Karena peneliti ingin meneliti tenaga kerja yang pernah dan akan berangkat kembali menjadi TKI, maka sampel tidak dapat diambil secara acak karena tidak setiap tenaga kerja yang ada di Balai Latihan Kerja Luar Negeri ( BLK-LN) pernah menjadi TKI sebelumnya. Dan variabel yang akan diukur dalam penelitian ini yaitu Remitansi (Y), Pendapatan $\left(\mathrm{X}_{1}\right)$, Tingkat Kebutuhan Keluarga TKI $\left(\mathrm{X}_{2}\right)$, Tingkat
Konsumsi TKI $\left(\mathrm{X}_{3}\right)$. Teknik pengumpulan data melalui wawancara terstruktur dengan menggunakan kuesioner. Jenis penelitian yang digunakan menggunakan data kuantitatif dengan menggunakan uji statistik dan metode analisis yang digunakan adalah analisis uji asumsi klasik, uji t, uji $\mathrm{F}$ dan pengujian koefisien determinasi (R2).

\section{HASIL DAN PEMBAHASAN}

\section{Regresi Linier Berganda}

Pengujian hipotesis dalam penelitian ini menggunakan analisis regresi linier berganda menggunakan program computer SPSS 17.0 diperoleh seperti terangkum pada tabel berikut :

Tabel 1. Hasil Analisis Linier Berganda

\section{Coefficients}

\begin{tabular}{|c|c|c|c|c|c|c|}
\hline & & \multicolumn{2}{|c|}{$\begin{array}{l}\text { Unstandardized } \\
\text { Coeff icients }\end{array}$} & \multirow{2}{*}{$\begin{array}{c}\text { Standardized } \\
\text { Coeff icients } \\
\text { Beta }\end{array}$} & \multirow[b]{2}{*}{$t$} & \multirow[b]{2}{*}{ Sig. } \\
\hline \multicolumn{2}{|c|}{ Model } & $\mathrm{B}$ & Std. Error & & & \\
\hline \multirow[t]{4}{*}{1} & (Constant) & -30887.2 & 407924.4 & & -.076 & .940 \\
\hline & Pendapatan & .713 & .073 & 1.017 & 9.734 & .000 \\
\hline & Kebutuhan Keluarga & .285 & .105 & .209 & 2.729 & .009 \\
\hline & Konsumsi Pribadi & -.738 & .148 & -.442 & -4.984 & .000 \\
\hline
\end{tabular}

a. Dependent Variable: Remitasi

Sumber: Data Penelitian diolah, 2016 
Berdasarkan hasil analisis pada tabel 1 maka persamaan regresi dalam penelitian ini adalah sebagai berikut: $\mathrm{Y} 1=1.017 \mathrm{X} 1+0.209$ $\mathrm{X} 2-0.442 \mathrm{X} 3+\mathrm{e}$

Persamaan regresi tersebut mempunyai makna sebagai berikut:

Nilai $\beta$ dari pendapatan sebesar 1.017 artinya apabila ada kenaikan dari nilai pendapatan dengan asumsi nilai variabel kebutuhan keluarga dan nilai variabel konsumsi pribadi konstan, maka nilai dari variable remitansi mengalami kenaikan.

Nilai $\beta$ dari kebutuhan keluarga sebesar 0.209 artinya apabila ada kenaikan dari nilai kebutuhan keluarga dengan asumsi nilai variabel pendapatan dan nilai variabel konsumsi pribadi konstan, maka nilai dari variabel remitansi mengalami kenaikan

Nilai $\beta$ dari konsumsi pribadi sebesar 0.442 artinya apabila ada kenaikan dari nilai konsumsi pribadi dengan asumsi nilai variabel pendapatan dan nilai variabel kebutuhan keluarga konstan, maka nilai dari variabel remitansi mengalami penurunan.

\section{Uji Asumsi Klasik}

\section{Uji Normalitas}

Uji normalitas dapat dilihat pada grafik Normal P-Plot sebagai berikut:

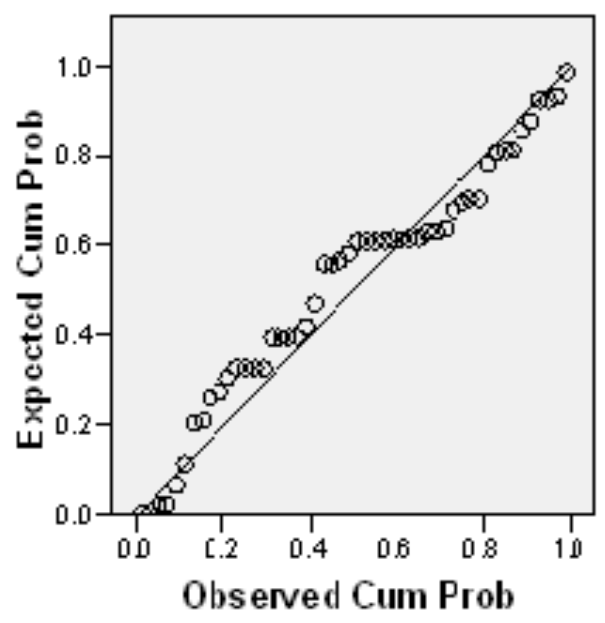

Gambar 2. Grafik Normal P-P Plot

Berdasarkan Gambar 2 diketahui bahwa normal. Untuk memastikan data terdistribusi titik-titik pada gambar normal probability plot normal dilakukan pengujian kedua dengan uji cenderung membentuk garis diagonal, sehingga statistik dengan melihat hasil Kolmogorovdapat disimpulkan bahwa model terdistribusi Smirnov sebagai berikut :

Tabel 2. Hasil Uii Normalitas dengan Kolmogorov-Smirnov

One-Sample Kolmogorov-Smirnov Test

\begin{tabular}{|ll|r|}
\hline & & $\begin{array}{r}\text { Unstandardiz } \\
\text { ed Residual }\end{array}$ \\
\hline N & & 50 \\
& Mean & .0000000 \\
Most Extreme & Std. Dev iation & 757189.5570 \\
Dif f erences & Absolute & .140 \\
& Positive & .091 \\
Kolmogorov-Smirnov Z & Negative & -.140 \\
Asy mp. Sig. (2-tailed) & & .991 \\
\hline
\end{tabular}

a. Test distribution is Normal.

b. Calculated from data.

Sumber: Data Penelitian diolah, 2016 
Berdasarkan tabel 2 diperoleh nilai sig $=$ $0.280=28 \%>5 \%$, maka data dikatakan terdistribusi secara normal.

\section{Uji Multikolonoeritas}

Uji multikolonieritas bertujuan untuk menguji apakah model regresi ditemukan adanya korelasi antar variabel bebas (independen). Model regresi yang baik seharusnya tidak terjadi korelasi antara variabel independen. Untuk mendeteksi ada tidaknya multikolonieritas di dalam model regresi adalah dengan melihat nilai tolerance dan Variance Inflation Factor (VIF). Apabila nilai tolerance > $10 \%$ dan nilai VIF $<10$, maka dapat disimpulkan tidak ada multikolonieritas antar variabel bebas dalam model regresi (Ghozali, 2011:105). Berikut hasil perhitungan menggunakan program SPSS 17:

Tabel 3. Hasil Uji Multikolonieritas

Coefficients

\begin{tabular}{|ll|r|r|r|r|r|}
\hline \multirow{2}{*}{ Model } & \multicolumn{3}{|c|}{ Correlations } & \multicolumn{2}{c|}{ Collinearity Statistics } \\
\cline { 3 - 7 } & & Zero-order & Partial & \multicolumn{1}{c|}{ Part } & Tolerance & \multicolumn{1}{c|}{ VIF } \\
\hline 1 & Pendapatan & .824 & .820 & .591 & .338 & 2.960 \\
& Kebutuhan Keluarga & .675 & .373 & .166 & .630 & 1.588 \\
& Konsumsi Pribadi & .337 & -.592 & -.303 & .469 & 2.134 \\
\hline
\end{tabular}

a. Dependent Variable: Remitasi

Sumber: Data Penelitian diolah, 2016

Berdasarkan Tabel 3 terlihat setiap variabel bebas mempunyai nilai tolerance $\geq 0,1$ dan nilai $\mathrm{VIF} \leq 10$. Jadi dapat disimpulkan bahwa tidak ada multikolonearitas antar variabel bebas dalam model regresi ini.

\section{Uji Heteroskedastisitas}

Uji heteroskedastisitas bertujuan menguji apakah dalam model regresi terjadi ketidaksamaan variance dari residual satu pengamatan ke pengamatan yang lain. Model regresi yang baik adalah yang homoskesdastisitas. Untuk menguji heteroskedastisitas dapat dilakukan dengan mengamati grafik scatterplot dengan pola titiktitik yang menyebar diatas dan dibawah sumbu Y. Berikut hasil pengolahan menggunakan program SPSS 17 :

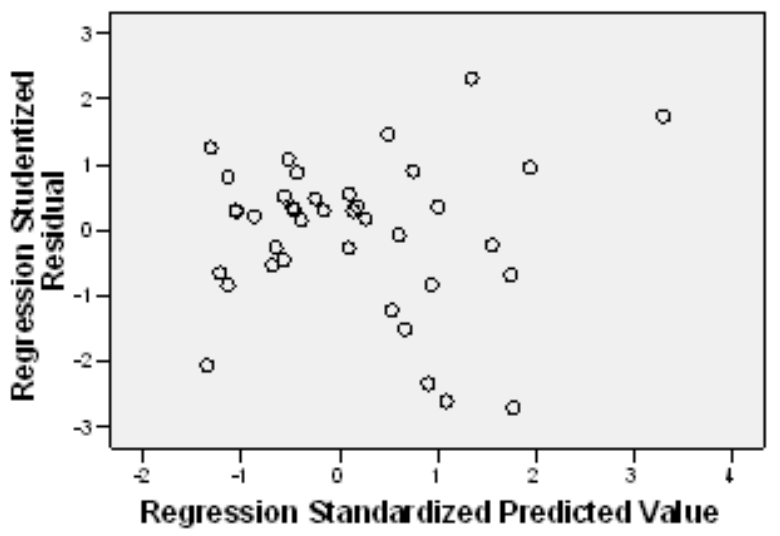

Gambar 3. Grafik Scatterplot

Pada gambar 3 grafik scatterplot terlihat bahwa titik-titik menyebar secara acak serta tersebar baik diatas maupun dibawah angka nol pada sumbu Y. Maka dapat disimpulkan tidak terjadi heteroskedastisitas pada model regresi ini. 
Selain mengamati grafik scatterplot uji heteroskedastisitas juga dapat dilakukan dengan uji Glejser. Uji glejser yaitu pengujian dengan meregresikan nilai absolute residual terhadap variabel independen. Output dari uji glejser pada tabel 4.5 adalah sebagai berikut:

Tabel 4. Hasil Uji Glejser

Coefficients

\begin{tabular}{|c|c|c|c|c|c|c|}
\hline \multirow{2}{*}{\multicolumn{2}{|c|}{ Model }} & \multicolumn{2}{|c|}{$\begin{array}{c}\text { Unstandardized } \\
\text { Coefficients }\end{array}$} & \multirow{2}{*}{$\begin{array}{c}\text { Standardized } \\
\text { Coefficients } \\
\text { Beta }\end{array}$} & \multirow[b]{2}{*}{$t$} & \multirow[b]{2}{*}{ Sig. } \\
\hline & & $\mathrm{B}$ & Std. Error & & & \\
\hline \multirow[t]{4}{*}{1} & (Constant) & 192785.4 & 226859.4 & & .850 & .400 \\
\hline & Pendapatan & .156 & .041 & .828 & 1.834 & .381 \\
\hline & Kebutuhan Keluarga & -.048 & .058 & -.131 & -.828 & .412 \\
\hline & Konsumsi Pribadi & -.274 & .082 & -.609 & -1.324 & .175 \\
\hline
\end{tabular}

a. Dependent Variable: AbRes

Sumber: Data Penelitian diolah, 2016

Pada tabel 4 dengan jelas menunjukkan semua variabel independen mempunyai nilai sig $\geq 0.05$. Jadi tidak ada variabel independen yang signifikan secara statistik mempengaruhi variabel dependen Absut. Hal ini terlihat dari nilai sig pada tiap-tiap variabel independen seluruhnya diatas 0.05 . Jadi dapat disimpulkan bahwa model regresi tidak mengandung adanya heteroskedastisitas.

\section{Uji Autokorelasi}

Uji autokorelasi bertujuan menguji apakah dalam model regresi linear ada korelasi antara kesalahan penganggu pada periode $t$ dengan kesalahan penganggu pada periode $t-1$ (sebelumnya). Salah satu cara untuk mendeteksi ada atau tidaknya autokorelasi yaitu dengan melakukan uji Durbin-Watson (DW-test). Berikut hasil pengolahan menggunakan program SPSS 17:

Tabel 5. Hasil Uji Autokorelasi

\section{Model Summary}

\begin{tabular}{|l|r|r|r|r|c|}
\hline Model & R & R Square & $\begin{array}{l}\text { Adjusted } \\
\text { R Square }\end{array}$ & $\begin{array}{c}\text { Std. Error of } \\
\text { the Estimate }\end{array}$ & $\begin{array}{c}\text { Durbin- } \\
\text { Watson }\end{array}$ \\
\hline 1 & $.911^{\mathrm{a}}$ & .830 & .819 & 781490.566 & 2.235 \\
\hline
\end{tabular}

a. Predictors: (Constant), Konsumsi Pribadi, Kebutuhan Keluarga, Pendapatan

b. Dependent Variable: Remitasi

Sumber: Data Penelitian diolah, 2016

Karena nilai DW (2.235) lebih besar dari nilai dU (1.674) dan kurang dari 4- 1.674 (4-dU) yakni 2.326 maka dapat disimpulkan bahwa tidak terjadi autokorelasi.

\section{Uji Signifikansi Parameter Individual (Uji Statistik t)}

Berdasarkan Tabel 1. diketahui bahwa :

a. Variabel pendapatan memiliki tingkat signifikansi sebesar 0.000 , dimana $0.000 \leq$
0.05, dapat disimpulkan bahwa variabel pendapatan berpengaruh positif dan signifikan terhadap remitansi. Dengan demikian maka $\mathrm{H} 1$ yang menyatakan "Ada pengaruh pendapatan TKI terhadap remitansi pada Kabupaten Cilacap" diterima.

b. Pada variabel kebutuhan keluarga memiliki tingkat signifikansi sebesar 0.009 , dimana $0.009 \leq 0.05$, maka dapat disimpulkan bahwa variabel kebutuhan keluarga berpengaruh 
positif dan signifikan terhadap remitansi. Dengan demikian maka $\mathrm{H} 2$ yang menyatakan "Ada pengaruh tingkat kebutuhan keluarga TKI terhadap remitansi pada Kabupaten Cilacap" diterima.

c. Pada variabel konsumsi pribadi memiliki tingkat signifikansi sebesar 0.000 dimana $0.000 \leq 0.05$, maka dapat disimpulkan bahwa variabel konsumsi pribadi berpengaruh negatif dan signifikan terhadap remitansi. Dengan demikian maka H3 yang menyatakan "Ada pengaruh tingkat konsumsi pribadi TKI terhadap remitansi pada Kabupaten Cilacap" diterima.

\section{Uji F (Uji Simultan)}

Uji $F$ digunakan untuk mengetahui apakah variabel-variabel independen secara simultan berpengaruh signifikan terhadap variabel dependen. Derajat kepercayaan yang digunakan adalah 0,05. Apabila nilai $F$ hasil perhitungan lebih besar daripada nilai $\mathrm{F}$ menurut tabel maka hipotesis alternatif, yang menyatakan bahwa semua variabel independen secara simultan berpengaruh signifikan terhadap variabel dependen. Hasil output dari SPSS adalah sebagai berikut:

Tabel 6. Hasil Uji F dengan variabel dependent Remitansi

ANOVA

\begin{tabular}{|ll|l|r|r|r|r|}
\hline Model & & $\begin{array}{l}\text { Sum of } \\
\text { Squares }\end{array}$ & df & Mean Square & F & Sig. \\
\hline 1 & Regression & $1.4 \mathrm{E}+014$ & 3 & $4.578 \mathrm{E}+013$ & 74.962 & $.000^{\mathrm{a}}$ \\
& Residual & $2.8 \mathrm{E}+013$ & 46 & $6.107 \mathrm{E}+011$ & & \\
& Total & $1.7 \mathrm{E}+014$ & 49 & & & \\
\hline
\end{tabular}

a. Predictors: (Constant), Konsumsi Pribadi, Kebutuhan Keluarga, Pendapatan

b. Dependent Variable: Remitasi

Sumber: Data penelitian diolah, 2016

Dari tabel 6 diperoleh nilai $F_{\text {hitung }}$ sebesar 74,962 dengan nilai probabilitas (sig) $=0,000$. Nilai $F_{\text {hitung }}(74,962)>F_{\text {tabel }}(2,79)$, dan nilai sig. lebih kecil dari nilai probabilitas 0,05 atau nilai $0,000<0,05 ;$ maka model regresi dapat digunakan untuk memprediksi pengiriman pendapatan TKI ke keluarga atau dapat dikatakan bahwa pendapatan, kebutuhan keluarga, dan konsumsi pribadi secara bersamasama berpengaruh terhadap pengiriman pendapatan TKI ke keluarga.

\section{Uji Koefisien Determinasi $\left(\mathbf{R}^{2}\right)$}

Koefisien determinasi $\left(\mathrm{R}^{2}\right)$ pada intinya mengukur seberapa jauh kemampuan model dalam menerangkan variasi variabel terikat. Nilai koefisien determinasi adalah antara nol sampai satu. Jika $\mathrm{R}^{2}$ mendekati satu (1) maka dikatakan semakin kuat model tersebut dalam menerangkan variasi variabel bebas terhadap variabel terikat. Sebaliknya jika $\mathrm{R}^{2}$ mendekati nol (0) maka semakin lemah variasi bebas menerangkan variabel terikat. Hasil output dari SPSS adalah sebagai berikut:

Tabel 7. Hasil Uji Koefisien Determinasi

Model Summart
\begin{tabular}{|l|c|c|c|c|}
\hline Model & R & R Square & $\begin{array}{c}\text { Adjusted } \\
\text { R Square }\end{array}$ & $\begin{array}{c}\text { Std. Error of } \\
\text { the Estimate }\end{array}$ \\
\hline 1 & $-911^{3}$ & -830 & -819 & 781490.566 \\
\hline
\end{tabular}
a. Predictors: (Constant), Konsumsi Pribadi, Kebutuhan Keluarga,
Pendapatan
b. Dependent Variable: Remitasi

Sumber: Data penelitian diolah, 2016 
Pada tabel 7 menunjukkan besarnya presentase variabel dependen mampu dijelaskan oleh variabel bebas yang ditunjukan dengan nilai Adjusted $R$ Square sebesar 0.819, dan dapat diartikan bahwa variabel dependen mampu dijelaskan oleh variabel independen sebesar $81.9 \%$ sedangkan sisanya sebesar $18.1 \%$ dijelaskan oleh variabel lain yang tidak diteliti dalam penelitian ini.

\section{SIMPULAN}

Berdasarkan hasil penelitian dan pembahasan, maka dapat disimpulkan sebagai berikut:

Secara parsial diperoleh hasil berikut: (a) Variabel pendapatan memiliki pengaruh positif dan signifikan terhadap pengiriman pendapatan TKI ke keluarga. Hal ini menunjukkan bahwa apabila pendapatan mengalami kenaikan maka jumlah pengiriman pendapatan TKI ke keluarga juga meningkat. (b) Variabel kebutuhan keluarga memiliki pengaruh positif dan signifikan terhadap pengiriman pendapatan TKI ke keluarga. Hal ini menunjukkan bahwa apabila kebutuhan keluarga mengalami kenaikan maka jumlah pengiriman pendapatan TKI ke keluarga juga meningkat. (c) Variabel konsumsi pribadi memiliki pengaruh negatif dan signifikan terhadap pengiriman pendapatan TKI ke keluarga. Hal ini menunjukkan bahwa apabila konsumsi pribadi TKI mengalami kenaikan maka jumlah pengiriman pendapatan TKI ke keluarga akan menurun.

Secara simultan

Nilai

$F_{\text {hitung }}(74,962)>F_{\text {tabel }}(2,79)$, dan nilai sig. lebih kecil dari nilai probabilitas 0,05 maka model regresi dapat digunakan untuk memprediksi pengiriman pendapatan TKI ke keluarga atau dapat dikatakan bahwa pendapatan, kebutuhan keluarga, dan konsumsi pribadi secara bersamasama berpengaruh terhadap pengiriman pendapatan TKI ke keluarga. Variabel pendapatan merupakan variabel paling dominan mempengaruhi remitansi dengan nilai $\beta$ sebesar 1,017 dan signifikansi sebesar 0,00

Berdasarkan simpulan yang telah dipaparkan maka dapat diajukan saran sebagai upaya untuk membantu mengatasi masalah tenaga kerja Indonesia (TKI) khususnya di wilayah Kabupaten Cilacap sebagai berikut : (1) Bagi TKI hendaknya memiliki rencana jangka panjang dalam mengelola pendapatan yang diperoleh selama menjadi TKI, dengan begitu ketika TKI kembali ke daerah asal mampu membangun usaha untuk menyambung hidupnya. (2) Bagi keluarga TKI diharapkan mampu bersikap bijak dalam menggunakan dana yang dikirimkan rutin untuk pemenuhan kebutuhan hidup keluarga.

\section{DAFTAR PUSTAKA}

Adams JR., R.H. \& Cuecuecha, A., 2013. The Impact of Remittances on Investment and Poverty in Ghana. World Development, 50, pp.24-40.

Albo, Adolfo., Ordaz Diaz, Juan Luiz., Ling, Juan Jose. 2012. Economic Watch Mexico: Evolution of Sending Remittances Mechanism Has Favored More Resources Sent at Lower Costs. In Economic Analysis of Economic Research Department at Mexico, January 17, p:1-13.

Apriliana, Dewi dan Luh Gede Meydianawathi. 2013. "Faktor - factor yang mempengaruhi pengiriman remitasi TKI asal Bali di Amerika Serikat". E-Jurnal Ekonomi Pembangunan Universitas Udayana, Vol. 2, No. 8, Agustus $2013: 1-11$

Ardana, I Ketut, Sudibia, I Ketut dan Wirathi, I.G.A Putu. 2011. Faktor-Faktor Yang Mempengaruhi Besarnya Pengiriman Remitan Ke Daerah Asal Studi Kasus Tenaga Kerja Magang Asal Kabupaten Jembrana Di Jepang. Dalam Jurnal Piramida Kependudukan Dan Pengembangan Sumber Daya Manusia, 7(1): h. 10-41.

Badan Nasional Penempatan dan Perlindungan Tenaga Kerja Indonesia. 2014..

Badan Pusat Statistik Jateng. 2014.

Becker, Garry, S. 1976. "Human Capital", The University Chicago Press : Chicago.

Dedy Eko Muthoharun. 2010. Jam Kerja, Pendapatan, dan Remitan Terhadap Pemungut Barang Bekas (Pemulung) di Kecamatan Denpasar Selatan Kota Denpasar, Denpasar, 13.

Faiqoh Z. Aliya. 2009. Analisis Pengaruh Remitansi TKI terhadap Kehidupan Ekonomi Indonesia oleh Bank Indonesia dengan Regresi Logistik Nominal. Thesis. Fakultas Ekonomi Universitas Diponegoro, Semarang. Diunduh 
darihttp://eprints.undip.ac.id/view/divisions $/$ sch $=5$ Fstat/2009.default.html pada tanggal 31 Juli 2015

Ferdinand, Augusty. 2011. Metode Penelitian Manajemen Pedoman Penelitian Untuk Penulisan Skripsi, Tesis, Dan Disertasi Ilmu Manajemen Edisi Ketiga. Semarang: Fakultas Ekonomika dan bisnis Universitas Diponegoro.

Ghozali, Imam. 2011. aplikasi analisis multivariate dengan program IBM SPSS19.Semarang :Badan Penerbit Universitas Diponegoro.

Guha, P., 2013. Macroeconomic effects of international remittances: The case of developing economies. Economic Modelling , 33, pp.292-305.

Gujarati, N. Damodar, Porter, C. Dawn. 2011. "Dasar-Dasar Ekonometrika Buku 1 Edisi 5". Salemba Empat: Jakarta.

Hasan, M. Iqbal. 2002. Pokok-pokok Materi Statistik 2 (Statistik Inferensif) Edisi Kedua. Jakarta: PT. Bumi Aksara

Hernanto. 1994. Ilmu Usahatani. Penebar Swadaya : Jakarta.

Kasto. 2002. Mobilitas Penduduk Dan Dampaknya Terhadap Pembangunan Daerah. Dalam Mobilitas Penduduk. Universitas Gadjah Mada.

Mantra, Ida Bagoes. 2003. Demografi Umum. Yogyakarta ; Pustaka Pelajar

Miller, Roger Leroy dan Roger E Meiners. 1993. "Teori Ekonomi Mikro Intermediate : Teori, Masalah Pokok dan Penerapan". Raja Grafindo Persada : Jakarta.

Mulyadi. 2001. "Akuntansi Manajement : Konsep, Manfaat, dan Rekayasa Edisi 3". Salemba Empat : Jakarta.

Octania, Kadek Yomi dan IGW Murjana Yasa. 2014. Remitan Dan Factor Penentunya Studi Kasus : Migran Risen Lelurahan Jimbaran Kecamatan Jimbaran. E-Jurnal EP Unud, 3 [9] : 421-430

Prishardoyo, B., \& Karsinah, K. (2015). Analisis Faktor-Faktor Yang Mempengaruhi Volume Transaksi Pasar Uang Antar Bank Di Indonesia Tahun 1983-2007. JEJAK : Jurnal Ekonomi Dan Kebijakan, 3(2).doi:http://dx.doi.org/10.15294/jejak.v3i 2.4655

R. Aísa, J. Andaluz \& G. Larramona, 2011. How does bargaining power affect remittances? Economic Modelling, 28, pp.47-54.
Saefullah, A D. 1994.Mobilitas Penduduk Dan Perubahan Di Pedesaan (Studi Kasus Di Jawa Barat). Dalam Majalah Kajian Ekonomi Dan Sosial, 23(7): h: $35-47$.

Sihombing, Haery., Mochamad Safarudin. 2007. Mari Kita Garap Para TKI (Produk dan Layanan Terhadap Pasar TKI dan "Remittance" dalam Perspektif Potensi Bisnis dan Sosial Diunduh dari http://sihombing15.files.wordpress.com/2007 $/ 12 /$ marikita-garap-tki..pdf pada tanggal 31 Juli 2015

Sholeh, Maimun. 2007. "Permintaan dan Penawaran Tenaga Kerja Serta Upah : Teori Serta Beberapa Potretnya di Indonesia". Jurnal Ekonomi dan Pendidikan, Volume 4 Nomor 1, April 2007 : 62-75.

Sihombing, Haery., Mochamad Safarudin. 2007. Mari Kita Garap Para TKI (Produk dan Layanan Terhadap Pasar TKI dan "Remittance" dalam Perspektif Potensi Bisnis dan Sosial). Diunduh dari http://sihombing15.files.wordpress.com/2007 /12/marikita-garap-tki.pdf pada tanggal 31 Juli 2015.

Sir, Y. (2015). Pengaruh Cadangan Wajib Minimum Dan Tingkat Suku Bunga Terhadap Inflasi Di Indonesia. JEJAK : Jurnal Ekonomi Dan Kebijakan, doi:http://dx.doi.org/10.15294/jejak.v5i1.46 32

Sukirno, Sadono, 2004, Makroekonomi Teori Pengantar. Edisi Ketiga. Penerbit Raja Grafindo Persada: Jakarta.

Undang-Undang Nomor 39 Tahun 2004 Tentang Penempatan dan Perlindungan Tenaga Kerja Indonesia di Luar Negeri.

Utami, D. (2015). Determinan Suku Bunga Pasar Uang Antar Bank Di Indonesia. JEJAK: Jurnal Ekonomi Dan Kebijakan, 5(1).doi:http://dx.doi.org/10.15294/jejak.v5i 1.4624 . 